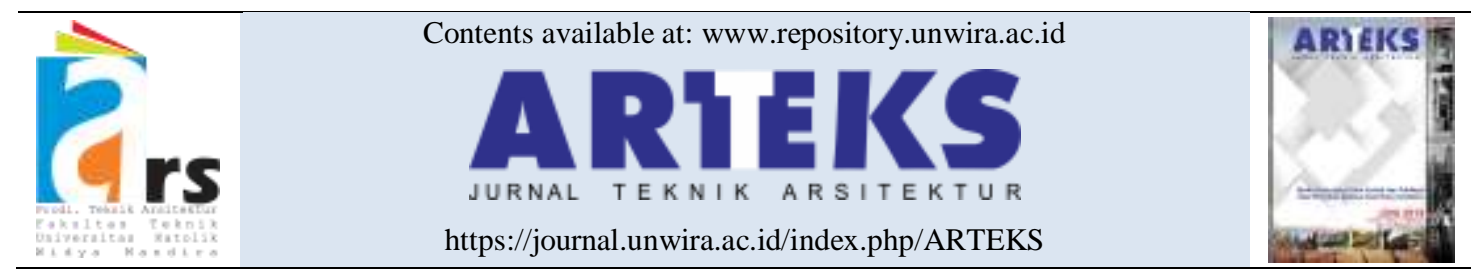

Research paper

doi: 10.30822/arteks.v6i2.691

\title{
A landscape architect preferences on border elements at green open spaces during Covid-19 pandemic
}

\author{
Dian Kartika Santoso* ${ }^{*}$, Irawan Setyabudi \\ Landscape Architecture Department, Universitas Tribhuwana Tunggadewi Malang \\ Jl. Telaga Warna, Tlogomas, Malang, Indonesia
}

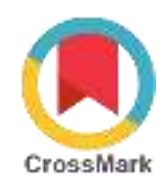

\begin{tabular}{|c|c|}
\hline ARTICLE INFO & ABSTRACT \\
\hline $\begin{array}{l}\text { Article history: } \\
\text { Received October } 10,2020 \\
\text { Received in revised form Nov. 16, } 2020 \\
\text { Accepted January } 01,2021 \\
\text { Available online August } 01,2021\end{array}$ & $\begin{array}{l}\text { Green open space has many benefits for humans. Unfortunately, the } \\
\text { function of green open space cannot be fully felt due to the Covid-19 } \\
\text { pandemic. Even though the application of physical distancing in the } \\
\text { garden can be created through the use of garden border elements. } \\
\text { As a first step in determining good and effective elements, this study }\end{array}$ \\
\hline $\begin{array}{l}\text { *Corresponding author: Dian Kartika } \\
\text { Santoso } \\
\text { Landscape Architecture Department, } \\
\text { Universitas Tribhuwana Tunggadewi Malang } \\
\text { Email: dian.kartika@unitri.ac.id } \\
\text { ORCID: https://orcid.org/0000-0001-6349- } \\
\text { 275X }\end{array}$ & $\begin{array}{l}\text { aims to explore the preferences of garden designers in selecting } \\
\text { garden border elements, their shapes, and arrangements to maintain } \\
\text { the distance between garden users. This research is a perceptual } \\
\text { research using a survey method obtained through distributing } \\
\text { questionnaires and processed by quantitative descriptive and chi- } \\
\text { square test. As for the results obtained in this study, garden } \\
\text { designers agree that the border element is an effective way that can } \\
\text { be used to implement physical distancing in public parks. Although, } \\
\text { in general, garden designers prefer hardscape over softscapes as a } \\
\text { border element, there are different preferences for the type of } \\
\text { hardscape and softscape used. Garden designers prefer fences, } \\
\text { portable benches }>2 m \text { apart and concrete construction as a } \\
\text { hardscape barrier that can be applied to gardens that have been } \\
\text { built. Meanwhile, the selection of softscape in the garden that has } \\
\text { been built tends to use flowering shrubs as a border element. The } \\
\text { conclusion of this study is the preference for material selection that } \\
\text { is different in terms of functionality and aesthetics is caused by the } \\
\text { pandemic. }\end{array}$ \\
\hline
\end{tabular}

\section{Introduction}

Green open space is open space in the form of an area or pathway which is part of a multipurpose system of spaces that are strongly connected to the development of an area on a large scale (Sukawi 2008). In the Minister of Public Works Regulation No. 05 / PRT / 2008, it is also stated that green open space is an area in linear or extensive form, with the function of growing plants either naturally or deliberately planted. The connotation of the word green in the term green open space refers to its designation as an area where plants grow naturally or through site engineering. Green open space has many benefits for humans.
Benefits are obtained through ecological functions (Blair 2009; Cameron et al. 2012), landscape function (Sukawi 2008), and aesthetic function (Malek et al. 2010). The aesthetic function is closely related to the color, size, texture, and shape of the vegetation arrangement connected to the environment. Ecological functions are related to providing oxygen, reducing environmental temperatures, space for living things, protecting the area from disasters, pollution and discomfort. Landscape function consists of physical functions such as protection against, sunlight, smells of wind and so on. The landscape function also includes social functions by providing a space for social interaction 
between citizens and a means of education and research (Sukawi 2008). The community park recreational function is also used as a means of leisure activities (Malek et al. 2010).

Unfortunately, the function of green open space cannot be fully felt due to the Covid-19 pandemic (Honey-Rosés et al. 2020). Public space, one of which is green open space during the Covid-19 pandemic, has experienced significant upheaval, shared space has become very limited as an effort to avoid spreading the virus (A. Kurniawan, Yumna, and Tantri 2020). In fact, green open space has benefits for the prevention of the Covid-19 virus. One of them is the provider of sufficient sunlight and healthy air circulation. As explained by several studies in the medical field, sunlight has proven to be effective in preventing and recovering from Covid-19 (Asyary and Veruswati 2020; Schuit et al. 2020). Poor air circulation in confined spaces is associated with increased transmission of respiratory infections. There have been many Covid-19 transmission events related to closed spaces. This analogy also applies to residential spaces, good air circulation is created with cross ventilation or there is no circulation barrier between the intake and outtake air, in spatial planning. The role of circulation in preventing the transmission of Covid-19 is very large (European Centre for Disease Prevention and Control 2020). So, the role of green open space is very large in providing access to direct sunlight and good air circulation. Circulation serves to distribute healthy air for the respiratory system (Atkinson et al. 2009).

One type of green open space that is most easily accessible and affected by Covid-19 is a community park. The outbreak of Covid-19 has forced some community parks to be closed to prevent transmission. In some countries, there are special protocols to prevent the transmission of Covid-19 in community parks. North Carolina State University formulated a protocol in the form of opening access to information for park users, especially regarding the prevention of covid-19 transmission, limiting the number of visitors to a maximum of 10 people per hour of visit, and users must maintain a minimum distance of 6 feet or 2 meters from other users (North Carolina State University 2020; Mejia et al. 2020). Meanwhile, the City of Durham government provides the following rules: maintain a distance of 2 meters ( 6 feet) from other people, limit the number of people in or around the park. If there is no fence around the garden, it is necessary to pay extra attention to ensure it. Placing physical distancing signs around parks, especially in high traffic areas, as well as eliminating sitting areas in parks (Durham 2020). The Horticultural Trades Association also suggests social distancing as an effort to prevent Covid-19 (The Horticultural Trades Association 2020). So, from three different institutions from three countries, an illustration can be obtained if physical distancing is a way that can be applied to prevent the transmission of Covid in Parks.

The alternative solutions offered by eliminating the sitting area as described above can actually be avoided through architectural elements. Physical distancing can be implemented using constraining elements. The problem is, most parks in Indonesia do not have clear boundaries in several areas, for example in the sitting area. In fact, with the introduction of new habitual adaptations, garden designers need to adapt to landscape designs that emphasize health protocols. Garden border elements have quite a variety of elements, ranging from softscapes to hardcapes. Poles, fences, paving, and concrete are alternatives to the hardscape barrier in the garden. Meanwhile, elements of the softscape that dividers the space in the garden can be obtained through dividing plants (H. Kurniawan and Alfian 2010; Setyabudi, Hastutiningtyas, and Olo 2017).

As explained above, the boundaries of the garden vary widely. As a first step in determining good and effective elements, this study aims to explore the preferences of garden designers in selecting garden border elements, their shapes, and arrangements to maintain the distance between garden users. With this research, it can be a reference for future landscape designers in designing gardens that are aesthetic, functional, and effective in preventing the spread of Covid19. This research is important and has never been done by other people with regard to architectural engineering in handling Covid-19.

\section{Method}

This research is a perceptual study using a survey method obtained from primary data by distributing questionnaires online via google form. The survey consists of a series of predefined questions that are given to the sample. With a representative sample, that is, a representative 
population (Creswell and Creswell 2018; Hu and Chang 2017). The population and sample are graduates of the landscape architecture study program who have been involved in the world of practitioners, so they are considered to understand the concept of design and landscape elements. The number of samples in this study were 30 respondents. The central limit theorem has been applied to a sample size of at least 30 . Even expressed for sample sizes greater than 20 , the normal distribution can be used to approximate the binomial distribution. The sample size is greater than 30 and smaller than 500, suitable for most studies (Alwi 2015; Kar and Ramalingam 2013).

The questions in the questionnaire are a type of closed question (closed ended question). Indicators and instrument questions that will be asked of respondents are obtained through the elaboration of the theory regarding the border element material in landscape design. The first indicator is the preference of landscape designers on the Covid-19 issue. Furthermore, the types of landscape elements commonly used consist of softscapes and hardscapes (Simond and Starke 2006). Softscape is also divided into several elements such as poles, fences (Durham 2020), concrete construction, paving (Elviana, Suryani, and Susanti 2018), signage, to the arrangement of benches with a safe distance of $2 \mathrm{~m}$ (Katz 2020). Meanwhile, softscape includes elements of plants, air, and soil (Tarakçı Eren, Düzenli, and Alpak 2018; Setyabudi, Hastutiningtyas, and Olo 2017; Simond and Starke 2006). The choice of materials and elements also looks at several factors that make it possible to obtain, price, material strength (durable), and produce aesthetic value (Nirmalasari, Lubis, and Kusuma 2017). Preference is seen in the condition of existing parks and parks that will be built in the future.

The results of the research will be analyzed using quantitative descriptive based on the highest number of scores for each of the options provided and chi-square analysis in seeing the differences in preferences of landscape designers in the built garden and the garden to be designed, using the following formula (Siegel 1986).

$$
\left.x^{2}=\sum_{i=1}^{\mathrm{k}}\left[\frac{(f o-f e}{f e}\right)^{2}\right]
$$

Keterangan:

$\mathrm{X} 2$ = Chi-square
Fo $=$ The number of respondents who chose the category in the attributes of the built park/garden to be designed

$\mathrm{Fe}=$ The number of respondents expected in the attributes of the built park/garden to be designed

i....k $=$ The attribute categories in the attributes in the built-in garden attributes and the garden to be designed.

$\mathrm{H} 0=$ There is no hardscape/softscape preference relationship to the garden that has been built and the garden to be designed $\mathrm{Ha}=$ There is a hardscape/softscape preference relationship to the garden that has been built and the garden to be designed

This Chi Square (X2) analysis consists of hypotheses (HO and $\mathrm{Ha}$ ) and has a 95\% confidence level with the testing criteria (X2 count $>\mathrm{X} 2$ table), then $\mathrm{H} 0$ is rejected and $\mathrm{Ha}$ is accepted, which means that there is a hardscape or softscape preference relationship in a park that has built and the garden to be designed; $X 2$ counts $<\mathrm{X} 2$ table, then $\mathrm{H} 0$ is accepted and $\mathrm{Ha}$ is rejected, which means that there is no hardscape or softscape preference relationship in the park that has been built and the park to be designed.

The data processing method used in this study uses tabulation with the help of Microsoft Office Excel 2016 software and IBM SPSS Statistics 25.

\section{Result and discussion}

According to the research results, the Covid-19 issue is being considered in the future park design process. As many as $80 \%$ of respondents considered it as an aspect of garden design, while $20 \%$ of respondents did not consider the Covid19 issue in designing the park (figure 1).
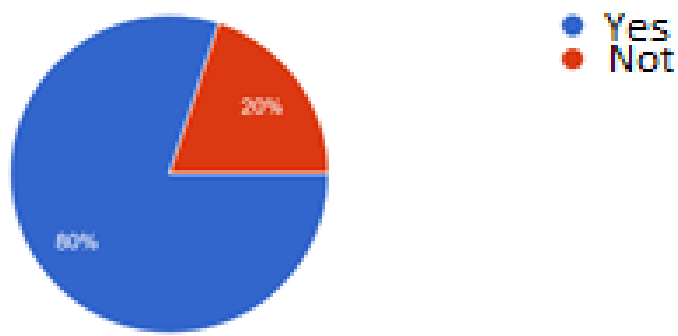

Figure 1. Preferences of landscape designers in considering the Covid-19 issue

One response that takes into account the Covid-19 issue is to limit user interaction by placing landscape elements. However, only 73.3\% of respondents stated that landscape elements were effective in limiting user interaction. Meanwhile 26.7\% of respondents stated that the use of landscape elements was not effective in limiting user interaction. 


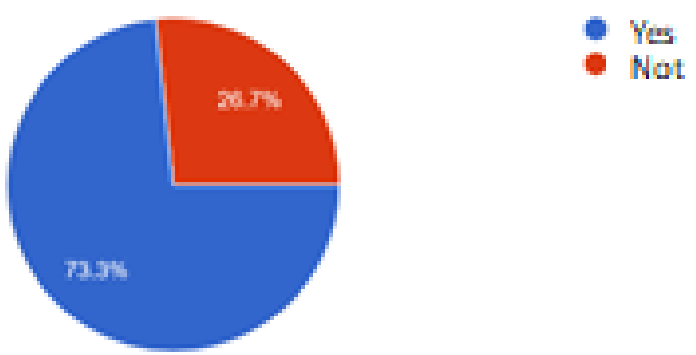

Figure 2. Preferences of garden designers about the effectiveness of the border elements

In this study, two-time settings were used to compare the preferences of landscape designers on the use of boundary elements in gardens that have been built and parks that will be designed in the future. More in detail will be discussed below.

Preference of landscape elements in the garden that has been built

As many as $60 \%$ of respondents stated that the hardscape element is more effective in limiting users in the park that has currently been built. Meanwhile, $40 \%$ of respondents stated that softscape elements were more effective in limiting users in parks or green open spaces.

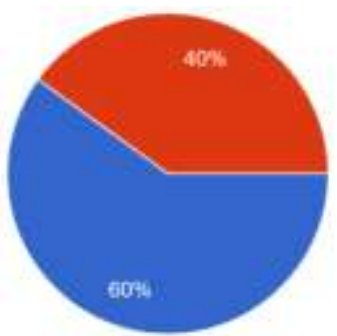

Hardscape - Sottacape

Figure 3. Preferences of garden designers regarding types of garden elements that are effective in limiting user interaction in a park that has been built

According to respondents, the most effective hardscape elements as a bounding element in a park that has been built are fences, portable benches $>2 \mathrm{~m}$ apart and concrete construction (20\%) followed by signage and static benches $>2 \mathrm{~m}$ apart (13.3\%), the rest is poles and paving.

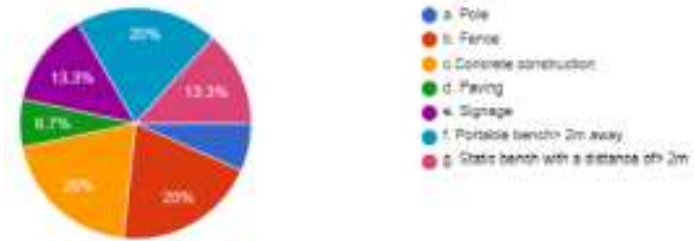

Figure 4. Preferences of garden designers regarding types of hardscape that are effective in limiting user interaction in an established park

Meanwhile, if using the softscape element as a barrier, the respondents chose flowering shrubs (26.7\% of respondents), non-flowering (leafly) shrubs (20\%), mounding and flowering shrubs (13.3\%) while the rest chose flowering trees, artificial rivers, leafly shrubs, and leafly trees.
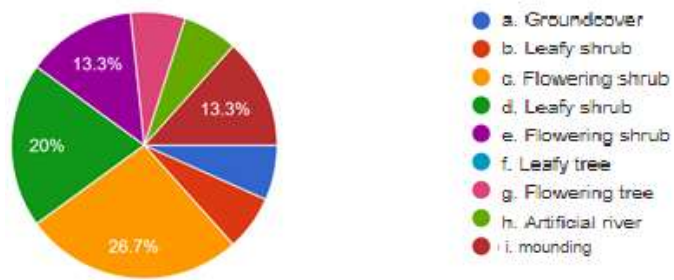

Figure 5. Preferences of garden designers regarding types of softcapes that are effective in limiting user interaction in a garden that has been built

Preference of elements of the boundary landscape in the garden to be designed in the future

As many as $66.7 \%$ of respondents stated that hardscape elements are more effective in limiting users in parks that will be designed in the future. Meanwhile, $33.3 \%$ of respondents stated that softscape elements were more effective in limiting users in parks or green open spaces.

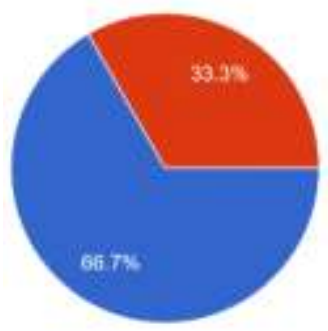

Figure 6. Preferences of garden designers regarding types of garden elements that are effective in limiting user interaction in the garden to be designed

Hardscape elements that become respondents' preferences in limiting interactions between users in the park to be designed in the future are paving (26.7\%), concrete construction $(26.7 \%)$, fences 
(20\%), signage (13\%) and the rest are portable benches and pole.
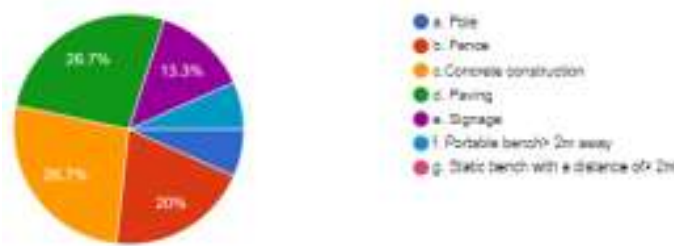

Figure 7. Preferences of garden designers regarding types of hardscape that are effective in limiting user interaction in the garden to be designed

According to respondents, the most effective softscape elements as a limiting element in the garden that will be designed in the future are artificial rivers (water features) as much as $26.7 \%$ of respondents, flowering shrubs by $20 \%$, mounding, leafly shrubs, and flowering shrubs respectively. $13.3 \%$, the rest are flowering trees and leafly shrubs.
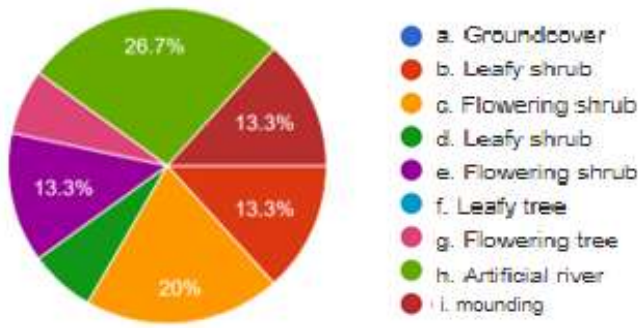

Figure 8. Preferences of garden designers regarding types of softcape that are effective in limiting user interaction in the garden to be designed

The difference in preferences of garden designers in the use of bounding elements in the garden that has been built and the garden that will be designed

The different preferences of garden designers in the use of boundary elements in the garden will be divided into two sub-discussions, namely softscape and hardscape. According to the Chisquare test, it was found that there was a relationship between hardscape and softscape preferences in the park that had been built and the garden to be designed.

The results of the analysis show that if $\mathrm{X} 2$ count $>\mathrm{X} 2$ table, namely $5.476>3.841$, then $\mathrm{H} 0$ is rejected and $\mathrm{Ha}$ is accepted, which means that there is a softscape preference relationship in the park that has been built and the garden to be designed.

The results of the analysis show that if X2 count $>\mathrm{X} 2$ table, namely $4,943>3,841$ then $\mathrm{H} 0$ is rejected and $\mathrm{Ha}$ is accepted, which means that there is a hardscape preference relationship in the park that has been built and the garden that will be designed.

The reason for selecting elements

Respondents had reasons for choosing the boundary landscape elements in the garden, as many as $48.7 \%$ of respondents argued that the elements used had aesthetic value, then $26.7 \%$ of respondents chose landscape elements because they were considered durable, $13.3 \%$ chose because they were environmentally friendly, the rest because it's cheap and easy to find.

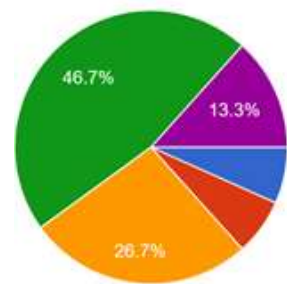

$$
\begin{aligned}
& \text { a. Chesp } \\
& \text { b. Easy to find (local) } \\
& \text { o. Durable } \\
& \text { d. Has aesthetic value } \\
& \text { e. Ecotriendly }
\end{aligned}
$$

Figure 9. Rationale for selecting elements

In general, landscape designers pay close attention to the Covid-19 issue in park design. Park designers also agree that the boundary element is an effective way that can be used to implement physical distancing in public parks. Although, in general, garden designers prefer hardscape when compared to softscape as a limiting element, but the types of hardscape and softscape have different preferences. The results show that there is a relationship between preferences for using boundary elements in parks (hardcape and softscape) to support physical distancing during the Covid-19 pandemic.

Garden designers prefer fences, portable benches $>2 \mathrm{~m}$ apart and concrete construction as a hardscape barrier that can be applied to an already built garden. Meanwhile, the softscape selection in the garden that has been built tends to use flowering shrubs as a limiting element. The difference in designer's preference can be seen clearly in the selection of hardscape and softscape in the garden that will be designed in the future with the selection of paving and concrete construction as the most effective hardscape barrier and water feature (artificial river) as the most effective softscape barrier in the garden that will be designed in the future. Basically, the choice of material or element is due to several factors, the most important thing according to the 
landscape designer is the aesthetic value and resistance of the selected landscape element.

When viewed from several previous theories and research, the selection of flowering shrubs as a limiting element has been widely used. Flowering shrubs that can be applied as a barrier include: Rhododendron obtusum, Bougainvillea sp, Pachystachys lutea, Pseuderanthemum reticulatum, Jasminum multiflorum, and Plumbago auriculata. These plants are types of plants that require $100 \%$ sunlight and watering that is not too frequent so they are very suitable for use in community gardens or public parks. The selection of hardscape elements in the form of concrete construction and portable benches is also a quick and instant solution that can be used in an established garden. So that the landscape designer preferences above can be widely used in the world of landscape architecture and the world of construction.

The differences in preferences seen in future garden design can also be understood by the use of paving, concrete construction, and the use of water features. The use of paving can be used for circulation (Hasim et al. 2015) which directs garden users to the place desired by the designer, concrete construction can also be chosen because of its strength and durability. Meanwhile, water feature selection can also be understood as an effort to direct the design user to the desired point by the designer. This is also explained by a theory which states that the design of a landscape can function as a guide for the users in it. In the end, the most important principle in the landscape design process is that it must meet functional and aesthetic principles (Simond and Starke 2006). The next research step is to look at user preferences for the physical distancing design obtained from this study. That way, the park remains a comfortable and safe area.

\section{Conclusion}

In general, landscape designers pay close attention to the Covid-19 issue in park design. Park designers also agree that the boundary element is an effective way that can be used to implement physical distancing in public parks. Although, in general, garden designers prefer hardscape over softscapes as a border element, there are different preferences for the type of hardscape and softscape used. Garden designers prefer fences, portable benches $>2 \mathrm{~m}$ apart and concrete construction as a hardscape barrier that can be applied to gardens that have been built. Meanwhile, the selection of softscape in gardens that have been built tends to use flowering shrubs as a limiting element. The difference in designer's preference can also be seen clearly in the selection of hardscape and softscape in the garden that will be designed in the future with the selection of paving and concrete construction as the most effective hardscape barrier and water feature (artificial river) as the most effective softscape barrier in the garden that will be designed in the future. front. Basically, the choice of material or element is due to several factors, the most important thing according to the landscape designer is the aesthetic value and resistance of the selected landscape element.

\section{References}

Alwi, Idrus. 2015. 'Kriteria Empirik Dalam Menentukan Ukuran Sampel Pada Pengujian Hipotesis Statistika Dan Analisis Butir'. Formatif: Jurnal Ilmiah Pendidikan MIPA 2 (2): $140-48$. https://doi.org/10.30998/formatif.v2i2.95.

Asyary, Al, and Meita Veruswati. 2020. 'Sunlight Exposure Increased Covid-19 Recovery Rates: A Study in the Central Pandemic Area of Indonesia'. Science of The Total Environment 729 (August): 139016. https://doi.org/10.1016/j.scitotenv.2020.1390 16.

Atkinson, James, Chartier Yves, Carmen Lucia Pessoa-Silva, Paul Jensen, Yuguo $\mathrm{Li}$, and Wing-Hong Seto, eds. 2009. Natural Ventilation for Infection Control in HealthCare Settings. Canbera: WHO. https://www.who.int/water_sanitation_health/ publications/natural_ventilation.pdf.

Blair, Dorothy. 2009. 'The Child in the Garden: An Evaluative Review of the Benefits of School Gardening'. The Journal of Environmental Education 40 (2): 15-38. https://doi.org/10.3200/JOEE.40.2.15-38.

Cameron, Ross W.F., Tijana Blanuša, Jane E. Taylor, Andrew Salisbury, Andrew J. Halstead, Béatrice Henricot, and Ken Thompson. 2012. 'The Domestic Garden - Its Contribution to Urban Green Infrastructure'. Urban Forestry \& Urban Greening 11 (2): 
129-37. https://doi.org/10.1016/j.ufug.2012.01.002.

Creswell, John W., and J. David Creswell. 2018. Research Design Qualitative, Quantitative, and Mixed Methods Approaches. 4th ed. New Delhi: SAGE Publications.

Durham. 2020. 'Community \& Allotment Gardens During COVID-19'. https://www.durham.ca/en/health-andwellness/resources/Documents/IllnessInfectio nDisease/FactsAbout/Novel-CoronavirusCommunity-And-Allotment-Gardens.pdf.

Elviana, Eva, Sri Suryani, and Wiwik Dwi Susanti. 2018. 'Elemen Pembentuk Ruang Terbuka Di Lingkungan Perumahan Sederhana'. JURNAL ENVIROTEK 8 (2). http://ejournal.upnjatim.ac.id/index.php/envir otek/article/view/949.

European Centre for Disease Prevention and Control. 2020. 'Heating, Ventilation and AirConditioning Systems in the Context of COVID-19'. European Centre for Disease Prevention and Control. 2020. https://www.ecdc.europa.eu/en/publicationsdata/heating-ventilation-air-conditioningsystems-covid-19.

Hasim, Irfan S., Bayyild Rizqan Syarif, Darel Raydar, and Abiel F. A. 2015. 'Rancangan Elemen, Sistem Sirkulasi, Dan Tata Hijau Lanskap Pada Lahan Kontur Di Hotel Padma Bandung'. Jurnal Rekakarsa 3 (1): 1-12. https://ejurnal.itenas.ac.id/index.php/rekakars a/article/view/631/1064.

Honey-Rosés, Jordi, Isabelle Anguelovski, Vincent K. Chireh, Carolyn Daher, Cecil Konijnendijk van den Bosch, Jill S. Litt, Vrushti Mawani, et al. 2020. 'The Impact of COVID-19 on Public Space: An Early Review of the Emerging Questions - Design, Perceptions and Inequities'. Cities \& Health, July, $1-17$. https://doi.org/10.1080/23748834.2020.1780 074.

Hu, Chih-Pei, and Yan-Yi Chang. 2017. 'John W. Creswell, Research Design: Qualitative, Quantitative, and Mixed Methods Approaches'. Journal of Social and Administrative Sciences 4 (2). https://doi.org/http://dx.doi.org/10.1453/jsas. v4i2.1313.

Kar, Sitanshu Sekhar, and Archana Ramalingam. 2013. 'Is 30 the Magic Number? Issues in Sample Size Estimation'. National Journal of Community Medicine 4 (1): 175-79. http://www.njcmindia.org/uploads/4-1_175179.pdf.

Katz, Hannah. 2020. 'Crisis Gardening: Addressing Barriers to Home Gardening during the COVID-19 Pandemic'. United States.

https://sustain.org.au/media/blog/Crisis-

Gardening-Addressing-Barriers-to-Home-

Gardening-during-the-COVID-19-

Pandemic.-.pdf.

Kurniawan, Andri, Nibrasatul Yumna, and Erna Tantri. 2020. 'Resistensi Ruang Publik Di Tengah Covid-19 Perspektif Islam Dan Komunikasi Multikultural'. KOMUNIKE 12 (1):

24-40. https://doi.org/10.20414/jurkom.v12i1.2253.

Kurniawan, Hendra, and Rizki Alfian. 2010. 'Konsep Pemilihan Vegetasi Lansekap Pada Taman Lingkungan Di Bunderan Waru Surabaya'. BUANA SAINS 10 (2): 181-88. https://doi.org/https://doi.org/10.33366/bs.v1 $0 \mathrm{i} 2.210$.

Malek, Nurhayati Abdul, Manohar Mariapan, Mustafa Kamal Mohd Shariff, and Azlizam Aziz. 2010. 'Assessing the Quality of Green Open Spaces: A Review'. In Healthy Parks Healthy People. HPHPcentral. https://www.researchgate.net/publication/236 941777_Assessing_the_Quality_of_Green_O pen_Spaces_A_review.

Mejia, Angie, Manami Bhattacharya, Amanda Nigon-Crowley, Kelly Kirkpatrick, and Chandi Katoch. 2020. 'Community Gardening during Times of Crisis: Recommendations for Community-Engaged Dialogue, Research, and Praxis'. Journal of Agriculture, Food Systems, and Community Development, October, 1-7. https://doi.org/10.5304/jafscd.2020.101.006.

Nirmalasari, Dindha, Irma H. Lubis, and Hanson Endra Kusuma. 2017. 'Hubungan Preferensi Material Dinding Rumah Dengan Nilai Ekologis'. In SMART \#2 - Seminar on Architecture Research \& Technology: Energy Efficient for Sustainable Living. Yogyakarta: Program Studi Arsitektur Universitas Kristen Duta Wacana Yogyakarta. https://smartfad.ukdw.ac.id/index.php/smart/ article/view/76/59.

North Carolina State University. 2020. 'Community Garden Guidelines during The Covid-19 Pandemic'. California.

Schuit, Michael, Shanna Ratnesar-Shumate, Jason Yolitz, Gregory Williams, Wade 
Weaver, Brian Green, David Miller, et al. 2020. 'Airborne SARS-CoV-2 Is Rapidly Inactivated by Simulated Sunlight'. The Journal of Infectious Diseases 222 (4): 564 71. https://doi.org/10.1093/infdis/jiaa334.

Setyabudi, Irawan, Wahidyanti Rahayu Hastutiningtyas, and Maria Nelde Olo. 2017. 'Konsep Aksesbilitas Dan Vegetasi Pada Taman Bermain Anak Difabel Di SLB-C Lawang'. BUANA SAINS 17 (1): 65. https://doi.org/10.33366/bs.v17i1.579.

Siegel, Sidney. 1986. Statistik Nonparametrik Untuk Ilmu-Ilmu Sosial. Jakarta: Gramedia Pustaka Utama.

Simond, John Ormsbee, and Barry Starke. 2006. Landscape Architecture: A Manual of Environmental Planning and Design. 4th ed. United States of America: McGraw-Hill Professional.

Sukawi. 2008. 'Taman Kota Dan Upaya Pengurangan Suhu Lingkungan Perkotaan (Studi Kasus Kota Semarang)'. In Peran Arsitektur Perkotaan Dalam Mewujudkan Kota Tropis. Semarang: UNDIP. http://eprints.undip.ac.id/973/2/Taman_Kota_
dan_Upaya_Pengurangan_Suhu_Lingkungan Perkotaan-fix.pdf.

Tarakçı Eren, Emine, Tuğba Düzenli, and Elif Merve Alpak. 2018. 'Plants That Are Used as Border Elements and Their Modes of Employment: KTU Campus Example'. Kastamonu Üniversitesi Orman Fakültesi Dergisi, September, 108-20. https://doi.org/10.17475/kastorman.344949.

The Horticultural Trades Association. 2020. 'HTA Safe Trading Guidance'. United Kingdom. https://hta.org.uk/uploads/assets/bd8b34da0289-45de-a120147de703aeeb/73c60a1c2ad5-41d3-bc59dfcc211472d4/HTA-SafeTrading-Guidance.pdf.

\section{Author(s) contribution}

Dian Kartika Santoso contributed to the research concepts preparation, methodologies, investigations, data analysis, visualization, articles drafting and revisions.

Irawan Setyabudi contribute to the research concepts preparation and literature reviews, data analysis, of article drafts preparation and validation. 